\title{
Motivation Among Female Sex Workers (WTS) To Undergo Vet As An Effort To Reduce Number of Hiv/Aids In Balekambang Localization, Bekasi
}

\author{
Wiwit Wijayanti ${ }^{1}$, Yulia Herawati ${ }^{2}$, Miftahul Jannah ${ }^{3}$ \\ \{ fara2708@gmail.com ${ }^{1}$, herawati.yulia1007@gmail.com², miftahuljannah29juli@gmail.com³ $\}$ \\ Study Program of Midwifery, Faculty of Health, MH. Thamrin University ${ }^{1}$ \\ Study Program of Midwifery, Stikes Mitra RIA Husada ${ }^{, 2,3}$
}

\begin{abstract}
Sex workers have a high potential to spread HIV/AIDS. Problems of this research are the lack of motivation for female sex workers (WTS) to undergo HIV/ AIDS testing. The research design was quantitative research and methods used was the analytic method with a cross-sectional approach. The number of a participant in this research were 70 people. The sample was taken using simple random sampling and using univariate and bivariate analysis. The results of the study showed that the lack of motivation of the female sex workers to undergo HIV testing/AIDS were as many as 42 respondents $(60,0 \%)$. Respondents who were less knowledgeable and had low motivation were $62.9 \%$ with $\mathrm{P}$ value 0.005 . Low social, economic respondents and low motivation $65.7 \%$ with $\mathrm{P}$ value 0.021 . Respondents who did not receive family support had a low motivation of $61.4 \%$ with $P$ Value 0.003 . Respondents who did not receive the support of health workers and had low motivation were $60 \%$ with $\mathrm{P}$ value 0,000 . Respondents who mentioned health facilities were inadequate and had low motivation were $67.1 \%$ with $\mathrm{P}$ value 0.001 . In conclusion, knowledge, socioeconomic, support family, support health workers, and health facilities cause very significant impact on motivation among female sex workers to undergo HIV/ AIDS testing, this can be seen from the fifth influence on the variables.
\end{abstract}

Keywords: Motivation, female sex workers/prostitutes (WTS), Voluntary Counselling Testing (VCT), HIV/AIDS

\section{Introduction}

Motivating and raising awareness in female sex workers (WTS) is very important to do because they can act as potential transmitters to spread HIV / AIDS to people who have not been infected. One of the efforts and government programs in tackling HIV / AIDS is early detection by VCT (Voluntary Counselling and Testing) test [1].

According to the World Health Organization (WHO) in 2013 from 37 million female sex workers, it was estimated that only $60 \%$ attended HIV / AIDS examinations. While in 2014 in East of Indonesia, especially Java Island, from 2.5 million female sex workers, only $40 \%$ were motivated to check their health in health providers to find out about HIV / AIDS infection. In 2015, in West Java, the government required every WTS to check their health at least once every six months. However, the program had not run well because from 1.1 million there were only $65 \%$ that were motivated to check their health [2]. 
The motivation of a health worker is very necessary in this regard. Thus they can maintain their health, and prevent further transmission of HIV / $\operatorname{AIDS}^{2}$. Some of the factors that influence WTS in participating in HIV / AIDS examination activities include education, knowledge, family support, information sources, economic status, environment, and support from health workers themselves that are supported by various government programs to achieve that goal [3].

According to the research conducted by Widodo (2009) in Yogyakarta, it is mentioned that there are 600 WTS who are still low in motivation to do VCT tests, but only $45 \%$ of female sex workers are motivated to undergo examinations at the nearest health facility. Likewise, with a study conducted by Sudaryat (2015) in Bogor, it was concluded that there was low interest in female sex workers to undergo HIV / AIDS tests which were influenced by various factors such as knowledge, socio-economic, family support and health workers and its surrounding environment [4].

Based on data obtained by researchers from Bungin Branch of Primary Health Care in the local area in 2016 as many as 85 WTS who examined their health especially reproductive health at the Primary Health Care, one of them was diagnosed with sexually transmitted infections (STI) and at the time there were no WTS diagnosed with HIV / AIDS. This is part of the obligation for health workers in the local area to improve early detection in every WTS to help control HIV-AIDS disease. Based on the above conditions, the researchers were interested in conducting a study on the Motivation among WTS to undergo VCT as an effort to reduce HIV / AIDS in Balekambang Localization, Bekasi.

\section{Methods}

The research design used in this study is quantitative analysis using a cross-sectional approach. This research was conducted from December 2016 to May 2017 in Balekambang Localization, Jaya Bakti Village, Branch Bungin District, Bekasi Regency. The population in this study were 110 WTS in Balekambang localization, Jaya Bakti Village, Branch Bungin Subdistrict, Bekasi Regency. The sampling technique used was a simple random sampling technique. The sample obtained was 70 WTS. The instrument used was a questionnaire with closed questions. Data analysis in this study was Bivariate Analysis using the Chi-Square test.

\section{Results}

The results of the study showed that out of 70 respondents, there were 42 respondents $(60.0 \%)$ who had low motivation, and only 28 respondents $(40.0 \%)$ were highly motivated. It was based on the results of data processing and by specific objectives in this study, namely to determine the frequency distribution and influence between knowledge factors, socioeconomic, family support, health personnel support, and health facilities with motivation for WTS to undergo HIV / AIDS testing.

Table 1. Factors influence the motivation among female sex workers to carry out HIV/ AIDS testing in Localization of Balekambang, Bekasi 


\begin{tabular}{|c|c|c|c|c|c|c|c|c|}
\hline \multirow{3}{*}{$\begin{array}{c}\text { Study } \\
\text { Variables }\end{array}$} & \multicolumn{5}{|c|}{ Motivation among WTS } & \multirow{3}{*}{$\begin{array}{r}\text { Total } \\
\%\end{array}$} & \multirow[t]{3}{*}{ OR } & \multirow[t]{3}{*}{ P Value } \\
\hline & \multirow[b]{2}{*}{$\mathbf{n}$} & \multicolumn{2}{|c|}{ Low } & \multicolumn{2}{|l|}{ High } & & & \\
\hline & & $\%$ & $\mathbf{n}$ & $\%$ & $\mathbf{n}$ & & & \\
\hline \multicolumn{9}{|l|}{ Knowledge } \\
\hline - Poor & 34 & 77,3 & 10 & 22,7 & 44 & 100 & 4,636 & 0,005 \\
\hline - Good & 11 & 42,3 & 15 & 57,7 & 26 & 100 & $(1,622-13,249)$ & \\
\hline \multicolumn{9}{|l|}{ Socioeconomic } \\
\hline - Low & 33 & 75,0 & 11 & 25,0 & 44 & 100 & 3,500 & 0,021 \\
\hline - High & 12 & 46,2 & 14 & 53,8 & 26 & 100 & $(1,250-9,800)$ & \\
\hline \multicolumn{9}{|l|}{ Family Support } \\
\hline - No Support & 37 & 77,1 & 11 & 22,9 & 48 & 100 & 5,886 & 0,003 \\
\hline - Support & 8 & 36,4 & 14 & 63,6 & 32 & 100 & $(1,962-17,664)$ & \\
\hline \multicolumn{9}{|c|}{ Health workers support } \\
\hline - No Support & 37 & 90,2 & 4 & 9,8 & 41 & 100 & 24,281 & 0,000 \\
\hline - Support & 8 & 27,6 & 21 & 72,4 & 29 & 100 & $(6,524-90,375)$ & \\
\hline \multicolumn{9}{|l|}{ Health facilities } \\
\hline - inadequate & 34 & 81,0 & 8 & 19,0 & 42 & 100 & 6,568 & 0,001 \\
\hline - adequate & 11 & 39,3 & 17 & 60,7 & 27 & 100 & $(2,229-15,359)$ & \\
\hline
\end{tabular}

\section{Discussion}

\subsection{Frequency distribution of motivation among WTS to carry out HIV / AIDS tests in Balekambang Localization, Bekasi.}

Motivation is a voluntary effort that influences a person's behavior that encourages to act and achieving certain results or goals. Among the experts came various opinions about motivation. Nevertheless, there is also a similarity in opinions that can be drawn regarding the notion of motivation, namely: the impulse from within a person that causes a person to carry out certain activities to achieve a goal. What can be observed is an activity or perhaps the reasons for the action [5].

Based on the results of the study it was found that out of 70 respondents there were 42 respondents $(60.0 \%)$ who had low motivation and 28 respondents $(40.0 \%)$ who had high motivation, those who had low motivation was greater than those with high motivation. Before conducting the research, validity and reliability tests have been carried out beforehand to test the accuracy of the instruments used and to obtain valid results.

This research was in line with the research conducted by Widodo in 2009 in Yogyakarta. It was stated that there were 600 WTS that had low motivation to undergo VCT tests and only WTS that were highly motivated to undergo health check-ups at the nearest health facility. Likewise, with the research conducted by Sudaryat in 2015 in Bogor, it was concluded that there was still a low interest among WTS in conducting tests on HIV / AIDS testing [4].

According to the researchers' assumption, the low motivation of WTS to carry out HIV / AIDS tests is influenced by various factors such as the lack of knowledge of respondents about HIV / AIDS tests which are very useful for early detection of sexually transmitted infections, socioeconomic factors where respondents mostly have low socioeconomic status, so there was no desire for health check-ups, and the lack of support from the family and from local health workers, making respondents to have low motivation to carry out HIV / AIDS tests, as well as factors from inadequate health facilities and distance from the place of 
residence respondents, thus causing respondents to have low motivation to carry out HIV / AIDS tests.

\subsection{Effect of knowledge on WTS motivation to carry out HIV / AIDS tests in Balekambang Localization, Bekasi.}

From the results of univariate research, it was found that out of 70 respondents, there were 44 respondents $(62.9 \%)$ who had less knowledge. Based on the results of the bivariate analysis, the P-value $=0.005$ means that knowledge has a significant effect because it is known that $\mathrm{P}$ value 0.005 is less than 0.05 which means that there is an influence between knowledge with motivation among WTS to undergo HIV / AIDS test.

This is by the theory that one's knowledge is usually obtained from experiences originating from various sources such as poster media, close relatives, mass media, electronic media, manuals, health workers, and so on. Knowledge can form certain beliefs so that someone behaves according to his beliefs [6].

While according to a study conducted by Sudaryat in 2015 in Bogor, it was concluded that there was a positive and significant relationship between knowledge with motivation among WTS to undergo HIV / AIDS testing where P value $=0.015$, the value was smaller than $\alpha=$ 0.05. Thus $\mathrm{HO}$ is rejected, or HI is accepted, meaning that there is an influence between knowledge with motivation among WTS to undergo HIV / AIDS testing [7].

This research is reinforced by research conducted by Verasati (2013) in Jember Regency who stated that knowledge on HIV / AIDS among WPS was still low, thus knowledge had a large influence on respondents' motivation to do VCT tests, where the $\mathrm{P}$ value $(0.001<0,05)$, then $\mathrm{H} 0$ is rejected. This means that there is a significant and positive influence between knowledge with motivation among WTS to carry out HIV / AIDS tests [8].

According to the researchers' assumption, there were more respondents who had less knowledge compare to respondents with good knowledge. This may be caused by several such as low education status, lack of sources on information about health tests given from health workers or from nearby families, lack of experience of respondents in participating in health screening activities, lack of interest of respondents in seeking various sources information about HV / AIDS, and the lack of counselling or health promotion activities by health workers, so that the presence of these factors can be a trigger for the low motivation among WTS to carry out HIV / AIDS testing.

\subsection{Socio-economic influence on motivation among WTS to carry out HIV / AIDS tests at Balekambang Localization, Bekasi.}

From the results of the univariate study, it was found that out of 70 respondents, there were 46 respondents $(65.7 \%)$ who had a low socioeconomic status. Based on the results of the bivariate analysis, the $\mathrm{P}$-value $=0.021$ which means that socio-economic has a significant effect because it is known that $\mathrm{P}$ value of 0.021 is less than 0.05 which means that there is an influence between socio-economic and motivation among WTS to carried out HIV / AIDS testing.

This is by the theory that the socio-economic position includes three factors, namely employment, education, and income. The above opinion was supported by the Mahbud UI Hag from the World Bank together with James Grant from the Overseas Development Council who stated that the socio-economic position was focused on health services, education, to see 
the socio-economic conditions of families or communities can be seen through three aspects, namely employment, education, and income [9].

Whereas according to research conducted by Fitrianita (2010) on Pandansimo Beach, Bantul, DIY, it was concluded that there was a significant influence between socio-economic income and the interest or motivation among WTS to conduct VCT test examination to know whether there was HIV / AIDS where P value $=0.002$, the value is smaller than $\alpha=0.05$. The $\mathrm{HO}$ is rejected or $\mathrm{HI}$ is accepted. Thus it means that there is an influence between socioeconomic income and motivation among WTS to carry out HIV / AIDS tests [10].

This research is also supported by research conducted by Miskawi (2009) in Banyuwangi district which stated that income from socio-economic had a large influence on the motivation of respondents to do VCT tests where the $\mathrm{P}$ value $(0.004<0.05)$, then $\mathrm{H} 0$ rejected. This means that there is a significant influence between socio-economic and motivation among WTS to carry out HIV / AIDS tests [11].

According to the researchers' assumption there were more respondents who had lower socioeconomic outcomes compared to respondents who had high socioeconomic conditions, this was due to various factors, one of them was that the income of WTS was not fixed every month, or it may be that the income earned was not enough compared to their daily needs, therefore, the motivation of respondents to carry out HIV / AIDS tests is very low. Also, there were other trigger factors such as lack of socialization of HIV / AIDS testing activities without cost carried out by health personnel and collaborating with members of the local government with perhaps the presence of these activities can motivate WTS to undergo health check-ups.

\subsection{Effect of Family Support on motivation among WTS to carry out HIV / AIDS testing in Balekambang Localization.}

From the results of the univariate study, it was found that out of 70 respondents, there were 43 respondents $(61.4 \%)$ who did not have family support. Based on the results of the bivariate analysis, the P-value $=0.003$ which means that family support has a significant effect because it is known that $\mathrm{P}$ value $0.003<0.05$ means that there is an influence between family support and motivation among WTS to carry out HIV / AIDS test.

This is by the theory that family support includes attitude, action, and family acceptance of its members. Family members are seen as part of the family environment. Family members view that supportive people are always ready to provide help and assistance if needed including in terms of motivating and supporting one family member or respondent in conducting a health check, especially on HIV / AIDS testing [12].

According to previous research conducted by Jahi (2009) in the West Java Rehabilitation Center, it was concluded that there was a significant relationship between the support of the family or the closest person to the motivation of the respondent to carry out HIV / AIDS testing where $\mathrm{P}$ value $=0.011$, the value was smaller than $\alpha=0.05$. So that $\mathrm{H} 0$ is rejected, or $\mathrm{HI}$ is accepted, it means that there is an influence between family support and motivation among WTS to carry out HIV / AIDS testing [7].

This research was also supported by research conducted by Tjipranoto (2009) in Sukabumi City, West Java, which stated that support provided by families for respondents had a large influence on respondents' motivation to carry out VCT tests where the $\mathrm{P}$ value $(0.002<0,05)$, then $\mathrm{H} 0$ is rejected. This means that there is a significant influence between family support and motivation among WTS to carry out HIV / AIDS tests [7]. 
According to the researchers' assumptions the results of the group of respondents who did not have family support were greater than those who had family support, this was due to the family background of the respondents who were mostly low educated, thus lack of knowledge on the importance of health check-ups and unable to provide optimal support to WTS to conduct health check-ups such as HIV / AIDS tests whereas other factors such as low family economic status and lack of good relations between WTS and the family members or other closest people can influence the lack of interest and motivation among WTS to carry out HIV / AIDS testing.

\subsection{Effect of Health Worker Support on motivation among WTS to carry out HIV / AIDS testing in Balekambang Localization, Bekasi.}

From the results of univariate research, it was found that out of 70 respondents, there were 42 respondents $(60.0 \%)$ who did not have the support from the health workers. Based on the results of the bivariate analysis, the $\mathrm{P}$-value $=0,000$ means that family support has a significant effect because it is known that $\mathrm{P}$ value $0,000<0,05$ means that there is an influence between the support of health workers and motivation among WTS to carry out HIV / AIDS.

By the theory (Indonesian Ministry of Health in 2011), the role of health workers (doctors, nurses, and midwives) in early detection of HIV has become more important because there are many people with HIV/ AIDS (PLWHA) whose HIV status is unknown, and that need medical services. Especially for female sex workers (WTS) who have a very dominant risk of transmission of HIV / AIDS. Support provided by health workers for WTS is in the form of counseling, health seminars, or promotion as part of government programs to improve public health.

According to research conducted by Sofa (2013) in Bungo district, it was concluded that there was an influence between the support of health workers with motivation and support for respondents to carry out HIV / AIDS testing where P value $=0.021$, the value is smaller than $\alpha$ $=0.05$. Thus that $\mathrm{HO}$ is rejected, or $\mathrm{HI}$ is accepted, meaning that there is an influence between the support of health workers and motivation among WTS to carry out HIV / AIDS testing [13].

This research is also supported by research conducted by Fitrianita (2010) in Jember Regency, stating that support from health workers for WTS respondents had a large influence on the motivation of respondents to conduct early detection examination with VCT tests where the $\mathrm{P}$ value $(0.006<0,05)$, then $\mathrm{H} 0$ is rejected, meaning that there is an influence between the support of health workers and motivation among WTS to carry out HIV / AIDS testing [10].

According to the researchers' assumptions the results of the group of respondents who did not have the support of health workers were more than the respondents who had the support of health workers, this was due to various factors including lack of knowledge among WTS about HIV / AIDS tests, which could affect their lack of interest in carrying out the health check-ups. There are also WTS who do not participate in health promotion carried out by health workers, and female sex workers who never pay attention to their health. Other factors include health workers who do not pay attention to the health of WTS, lack of effectivity in programs carried out by the government or health education or counseling on a sexually transmitted disease that are less effective. These factors can result in a lack of optimal motivation among WTS to carry out HIV/ AIDA testing. 


\subsection{Effect of Health Facilities on motivation among WTS to carry out HIV / AIDS tests in Balekambang Localization, Bekasi Regency.}

From the results of the univariate study, it was found that there were 47 respondents $(67.1 \%)$ out of 70 respondents who stated that there are inadequate health facilities. Based on the results of the bivariate analysis, the $\mathrm{P}$-value $=0.001$ means that inadequate health facilities have a significant effect because it is known that $\mathrm{P}$ value $0.001<0.05$ means that there is an influence between inadequate health facilities with motivation among WTS to carry out HIV / AIDS testing.

By the theory, the place to provide health services to the community to improve the health status is the Primary Health Care (PHC). However, the distance between the PHC and the housing are often quite far. Also, the facilities, especially on HIV-STD services on PHS as the primary health service, district/city hospitals as secondary health services and provincial hospitals as tertiary health services are often inadequate [14,15].

According to research conducted by Miskawi (2009) in Banyuwangi, it was concluded that there was a relationship between the condition of health facilities with motivation or interest of respondents to carry out HIV / AIDS testing where the P-value $=0.007$, the value was smaller than $\alpha=0.05$. Thus the H0 is rejected, or HI is accepted, meaning that there is a relationship between the support of health workers with motivation among WTS to carry out HIV / AIDS testing [11].

This study was also supported by a study conducted by Jahi (2009) in West Java, stating that the unavailability of health facilities had a large influence on the motivation of respondents to carry out HIV / AIDS testing where the P value $(0.001<0.05)$, then H0 rejected. This means that there is a significant relationship between health facilities with motivation among WTS to carry out HIV / AIDS tests [7].

According to the assumption of the researchers was that there were more respondents stating that there were inadequate health facilities compare to stating that there were adequate health facilities. This was due to various factors including limited resources and funding sources of local government in facilitating the implementation of HIV / AIDS testing programs, lack of special room facilities to conduct HIV / AIDS tests, inadequate laboratories, lack of programs in the prevention of HIV / AIDS, lack of knowledge of health workers in terms of proper health facility equipment standards, and lack of comfort for WTS at local health facilities, thus influences the motivation of the WTS to carry out an HIV / AIDS test.

\section{Conclusion}

There were more respondents who have low motivation compared to the respondents who had high motivation. There is an influence between knowledge, socio-economic, family support, support of health workers and health care facilities on the motivation of female sex workers (WTS) to carry out HIV / AIDS test in Localization of Balekambang, Bekasi Regency. The recommendations given are that health workers can schedule health education through counseling in the localization of Balekambang and hope to be more active to embrace the managers and residents in the localization to conduct VCT so that STD transmission can be reduced. 


\section{References}

[1] Murtiastutik D .:HIV \& AIDS,Buku Ajar Infeksi Menular Seksual (Surabaya).pp.45-50. (2008)

[2] Kementrian Kesehatan RI.: Badan Statistik Kasus HIV/AIDS (Jakarta: Pusat Data dan Informasi Kementrian Republik Indonesia).pp.34-50.(2011)

[3] Baratawidjaja K G.; Rengganis I Defisiensi Imun In: Imunologi Dasar Eds.8 (Jakarta: Salemba Medika).pp.20-30.(2009)

[4] Widodo E.;Praktik Wanita Pekerja Seks (WPS) Dalam Pencegahan Penyakit Infeksi Menular Seksual (IMS) Dan HIV \& AIDS Di Lokalisasi Koplak Promosi Kesehatan Indonesia.Vol.4.pp.94102.(2009)

[5] Santrock.:Psikologi Pendidikan/Educational Psyhchycology (Jakarta: Salemba Humanika).pp.3450.(2009)

[6] Notoatmodjo, Soekidjo.;Pendidikan dan Perilaku Kesehatan (Jakarta: Rineka Cipta).pp.3440.(2010)

[7] Sudaryat, Jahi,Tjitropranoto.:Karakteristik Wanita Tuna Susila (WTS) di panti Rehabilitas Jawa Barat Jurnal Penyuluhan Maret 2009 Vol.5.pp.1-9.(2009)

[8] Verasati,Andin.:Motivasi Wanita Pekerja Seks (WPS) dalam melakukan Tes HIV/AIDS Jurnal Studi Kualitatif di Kabupaten Jember.pp. 1-19.(2013)

[9] Daniel, Moehar.Metode Penelitian Sosial Ekonomi (Jakarta: Bumi Aksara).pp.30-42.(2010)

[10] Fitrianita. Upaya Pemberdayaan Wanita Tuna Susila (WTS) di panti Pandansimo Kabupaten Bantul, Yogyakata.pp.4-8. (2010)

[11] Miskawi. Menguak. WTS Antara Peran Positif Terbaikan dan Termarginalkan dalam Bentuk Pembelaannya untuk HAK Kesehatan Reproduksi (Pemeriksaan Kesehatan Tes HIV/AIDS).(2009)

[12] Wadyawati.;Pengaruh Dukungan Keluarga Terhadap Perubahan Respon Sosial Ekonomi. Skripsi: Program Studi Ilmu Keperawatan Fakultas Kedokteran Universitas Airlangga Surabaya.pp.3038.(2010)

[13] Sofa, Marya.:Peranan Pengetahuan, Keyakinan dan Sikap mengenai HIV/AIDS terhadap Perilaku Seksual Remaja di Kabupaten Bungo Jurnal IPTEKS Terapan Vol 8.pp. 199-209. (2013)

[14] Syamsiar S. Russeng, Lalu Muhammad saleh, Devintha Virani, Ade Wira Listrianti Latief, Anwar Mallongi.: The Investigation of the Lactic Acid Change among employee of national electrical Power Plan. Indian Journal of Public Health Research \& Development,Vol. 9.pp.3-18.(2013)

[15] Kementrian Kesehatan.:Buku Panduan Prktis Klinik di Fasilitas Kesehatan (Jakarta: Departemen Kesehatan Republik Indonesia)pp.1-25 (2015) 